\title{
Basic research in Kidney Cancer
}

\author{
Egbert Oosterwijk ${ }^{1,6}$, W. Kimryn Rathmell ${ }^{2}$, K. Junker ${ }^{3}$, A. Rose Brannon ${ }^{2}$, Frédéric \\ Pouliot $^{4}$, David S. Finley ${ }^{4}$, H. Uemura ${ }^{5}$, and Arie Belldegrun ${ }^{4}$
}

${ }^{1}$ Department of Urology, University Medical Center Nijmegen, Nijmegen, The Netherlands ${ }^{2}$ Lineberger Comprehensive Cancer Center, University of North Carolina at Chapel Hill, Chapel Hill, NC 27599,USA ${ }^{3}$ Department of Urology, University Hospitals, Friedrich-Schiller University Jena, Jena, Germany ${ }^{4}$ Institute of Urology, Department of Urology, University of California, Los Angeles, CA, USA ${ }^{5}$ Hirotsugo Uemura, Department of Urology, Kinki University School of Medicine, Osaka-Sayama, Osaka, Japan

\section{Introduction}

Cancer of the kidney is expected to affect almost 100.000 patients in the United States and European Union in 2010[1;2]. Renal cell carcinomas (RCC) refer to cortically derived tumors of the renal parenchyma and encompass a heterogeneous group of cancers[3]. Advances in basic research aimed at defining pivotal molecular events in the development of these different entities has shown that renal cancers can be subdivided based on genetic profiles. Moreover, knowledge of underlying molecular characteristics identified the vascular endothelial growth factor (VEGF) and the mammalian target of rapamycin (mTOR) pathways as fundamental to the biology of clear cell RCC. This biologic insight provided a rationale for targeting these growth factor signaling pathways in RCC.

Basic science in RCC is a vast area therefore we will focus on four areas of research that were felt most relevant for renal cancer and are not discussed in-depth in other chapters: the molecular basis of renal cancer, targeted therapies, renal cancer and immunity, and genetic factors and RCC. Finally, it is important to note that great majority of basic research in RCC is focused on clear cell RCC given the high prevalence of this histological subtype. Additionally, while the vast majority of studies have been performed on material from primary lesions, future studies should consider examination of metastatic lesions as well.

\section{The molecular basis of renal cancer}

Historically, four main histological renal cancers were recognized in the Heidelberg classification: clear cell Renal Cell Cancer (ccRCC, 60-80\%), papillary RCC (10-15\%), chromophobe RCC ( 5\%) and renal oncocytoma $(\sim 5 \%)[3 ; 4]$ Recently, translocation linked[5;6], mucinous tubular and spindle type RCC[7] and tubulocystic carcinoma[8] (all comprising $<1 \%$ of cases) have been added to this list. It is now clear that these

${ }^{6}$ Corresponding author: Egbert Oosterwijk, 267 Experimental Urology, Department of Urology, University Medical Center Nijmegen, 6500 HB Nijmegen, The Netherlands. 
morphological subtypes represent highly dissimilar diseases in both genetics and clinical behavior, and thus may or may not be variants of a common cancer or common cell of origin.

The biology of the von Hippel-Lindau ( VHL) gene product, pVHL, and its regulation of the hypoxia inducible factor (HIF) family of hypoxia-regulated transcription factors, is tightly linked to ccRCC biology. The discovery of the $V H L$ gene, and its association with the $V H L$ syndrome of central nervous system hemangioblastomas, pheochromocytoma/ paraganglioma, and ccRCC, in 1993[9] quickly led to the discovery that VHL mutation is also tightly associated with sporadic ccRCC, detected in up to $90 \%$ of tumors[10-13]. The loss of VHL leads to the loss of regulation of HIF family members HIF1a, HIF2a[14-18], and HIF3a[19], which is further composed of several splice variants. Xenograft studies have demonstrated that restoration of pVHL expression or suppression of deregulated HIF2a impairs the growth of these tumors[20;21].

Papillary RCC, chromophobe RCC and renal oncocytoma are less dominated by mutations in a single gene. Mutations in c-met have been associated with familial papillary type 1 RCC, but only in a subset of sporadic papillary RCC, and is thus less dominant than $V H L$ is for ccRCC[22]. A more rare, but also highly aggressive type of papillary type II renal cell carcinoma has been associated with mutations in the fumarate hydratase gene [23], although the relevance of this mutation in sporadic disease is unknown. Heterozygous knock-out of the gene implicated in the Birt-Higg-Dubé (BHD) syndrome in mice leads to the development of renal cysts and three different histological types of renal tumors, similar to human BHD which is closely associated with familial chromophobe RCC, but predisposes to other histologies as well [24].

In spite of the tight correlation of ccRCC with inactivation of $V H L$, the effect on HIF deregulation is not uniform: variant mutations in $V H L$ may contribute to imbalances of HIF1a and HIF2a deregulation, leading to distinct effects on cell growth[25;26]. In a strategy to determine whether tumors could be defined based upon the most studied and understood pathway in RCC, gene expression profiles were linked with $V H L$ mutation analysis and expression characteristics of the HIFs[27]. In this study, 160 ccRCCs were classified as $V H L$ mutant or wild type and according to HIF protein expression. $V H L$ mutant, HIF1 and HIF2 expressing tumors $(\mathrm{H} 1 \mathrm{H} 2)$ overexpressed the Akt/mTOR pathway, while VHL mutant tumors expressing solely HIF2 (H2 tumors) replicated more rapidly, marked by overexpression of $\mathrm{Ki}-67$, which other groups have identified as a poor-risk marker[28]. ccRCC can thus be characterized as $\mathrm{H} 1 \mathrm{H} 2$ or $\mathrm{H} 2$, with dramatically differing effects on tumor cell proliferation and C-myc regulation[27]. Recent evidence suggests that the $\mathrm{H} 2$ tumors may be derived from $\mathrm{H} 1 \mathrm{H} 2$ tumors that lose HIF1a in a subset of tumors, suggesting a potentially selective pressure to lose the HIF1a gene during tumor progression[29]. These insights potentially narrow the key tumorigenic events within the VHL/HIF axis.

Besides $V H L$ loss and HIF activation, major efforts have yet to identify a simple linear progression of genetic lesions accounting for the gains in aggressiveness in RCC[30-34]. Two recent ccRCC cytogenetic studies lend clues to understanding this progression. One 
study performed both single nucleotide polymorphism (SNP) analysis and gene expression analysis on sporadic ccRCC and tumors from patients with $V H L$ disease[30]. Importantly, this study demonstrated that tumors from sporadic and $V H L$-disease ccRCC tumors have overall similar profiles, but sporadic tumors are more heterogenous and contain a higher number of genetic events per tumor, but they cannot be distinguished using unsupervised analysis of gene expression data. In a prospective analysis of $282 \mathrm{ccRCC}$ patients with up to 108 months of follow-up using traditional cytogenetic karyotyping techniques[32] chromosomal loss at $3 p$ (the genomic home of the $V H L$ gene) was significantly associated with improved disease-specific survival, while losses of $4 p, 9 p$ and $14 q$ were significantly associated with reduced disease-specific survival, but the specific genes in these regions implicated in causing the poor prognosis remain to be characterized.

The first whole sequencing study in ccRCC confirmed that considerable genetic heterogeneity exists in ccRCC [29] emphasizing that even though the vast majority of ccRCC contain mutated $V H L$ most likely every tumor has a unique gene signature. This study also substantiated findings in multiple mouse knock-out studies and a zebrafish study which demonstrated that $V H L$ mutations/knock out alone is insufficient to produce ccRCC and that additional genetic events are required [35;36].

Although unable to cause sporadic ccRCC alone, the presence and type of $V H L$ mutations in tumors have been consistently considered as possible biomarkers. Cowey, et al, recently reviewed its potential in prognosis and prediction[37]. Further research is still required to establish VHL's efficacy as a biomarker, but given the frequency of its inactivation, more opportunities to understand the heterogeneity of this disease may lie in exploration of downstream factors. When $V H L$ is inactivated and HIF expression constitutively stabilized, a host of other genes which make up various components of the hypoxia response are transcriptionally upregulated (reviewed in[38]). It remains to be determined which of these factors or pathways most significantly contributes to the formation or maintenance of ccRCC's malignant phenotype. One HIF target, the vascular endothelial growth factor (VEGF), has been found to be significantly upregulated in kidney tumors compared to its elevated expression in many other cancers. As a prognostic biomarker, VEGF has not been proven to be valuable, but may be predictive of response to VEGF targeted therapy, as described below.

In order to identify more effective biomarkers and further understand the underlying biology, several different groups performed gene expression analyses on ccRCC tumor samples. Table 1 gives an overview of these studies. One of the initial expression profiling studies examined 29 ccRCC tumors, identifying 51 genes that could classify tumors based on 5 year disease-specific survival[39]. This study verified the possibility that gene expression profiles could be used to predict outcome in ccRCC, but remains to be validated or defined by biological parameters that may account for this difference in disease activity. One study of 51 tumor samples identified vascular cell adhesion molecule-1, VCAM-1, as a prognostic biomarker [40], which has subsequently undergone retrospective validation [41;42]. Importantly, high expression of this molecule predicted for better overall survival in both clear cell and papillary tumors, suggesting that VCAM-1 expression may generally indicate 
tumor cells with lower metastatic potential. The further implications for sensitivity to antiangiogenic therapy are not yet known.

Several gene signatures for RCC progression, for example three genes (caveolin 1, lysyl oxidase, and annexin A4) have been identified as associated with RCC aggression and/or survival[43] [44]. Similarly, survivin was shown to independently predict clear cell progression and risk of death [45][46]. Finally, the largest study, analyzing 177 clear cell tumors, identified 340 transcripts (including VCAM-1) significant in multivariate analysis with stage, grade and performance status[47][48].

While the above studies focused on clinical endpoints in their analyses, many started with an unsupervised analysis to get a general understanding of the data. The study that identified VCAM-1 as a prognostic biomarker saw the presence of potentially two subgroups within the stage IV tumors, with survival differences[40]. This suggests that molecular features beyond clinical staging could provide informative data in understanding even metastatic tumor behavior. The group of Zhao, et al. examined their 177 tumors using 3,674 genes also observed two larger groups of ccRCC, with significant survival differences as well as predicted biological pathway distinctions[47]. These studies helped to set the stage for further delineation of subgroups within ccRCC.

Two other studies stand out as being predominantly geared toward identifying the inherent subgroups and underlying biological differences of ccRCC. One group first looked at 16 ccRCC tumors and saw that there seemed to be two types of clear cell, one that more highly overexpressed metabolic genes and the other extracellular matrix/cell adhesion genes[49]. Most recently, a bioinformatic technique called unsupervised consensus clustering was used on 48 tumors to identify two subtypes of ccRCC, $c c A$ and $c c B$, distinguished by fewer than 120 probes[50]. Validating these results in the Zhao, et al., data set of 177 tumors, patients with ccA tumors have a marked survival advantage over those with ccB tumors. Additionally, this dataset validates the characteristics that $\mathrm{ccA}$ tumors display a profile of altered metabolism, whereas $\mathrm{ccB}$ tumors display characteristics of wound healing and epithelial to mesenchymal transition.

Finally, one study focused entirely on metastases[51], finding that late occurring metastases more highly expressed genes involved in angiogenesis, cell migration and adhesion. Additionally, genes related to cell division and cell cycle were overexpressed in samples from patients with multiple metastases, indicating that the presence of more metastases might be caused by an increased growth potential.

All of the potential biomarkers emerging from the gene expression studies require removal and processing of at least part of the tumor. Plasma serum proteins have traditionally been studied to find non-invasive diagnostic markers for the presence of ccRCC as compared to normal or benign renal tissue. Currently, there are no circulating tumor markers available for clinical use in management of RCC. Several molecules have been studied as candidates for diagnosis of RCC: In clear cell RCC the results with VEGF and VEGFR have been contradictory[52;53], and these markers might be more suitable as predictive than as diagnostic markers. Recent studies have shown elevated CAIX levels in ccRCC patients[54], 
with a significant association between CAIX serum levels and occurrence of metastases[55]. Furthermore, in patients with localized disease an elevated CAIX level predicts the recurrence and is correlated with a shorter PFS. Again, there is not a complete concordance with tissue results. Other markers related to tumor biology like MMP-7, CD95, bFGF, hepcidin-25, Il-10 or IL-6 showed promising results as possible biomarkers for RCC[5660], but these markers need to be validated in separate studies.

Because of the complexity of the tumor development and progression, identification of complex protein signatures is more promising. High throughput technologies like MALDI (Matrix-assisted laser desorption/ionization) or SELDI (Surface Enhanced Laser Desorption/ Ionisation) allow the analysis of the whole proteome of many samples in a short time with high sensitivity. SELDI-TOF-MS (Time of Flight Mass Spectrometry) has especially been used to define prognosis related profiles. Unique protein signatures of tumor patients compared to normal controls with high sensitivity (70-87\%) and specificity (89.9-92\%) have been described[56-63]. One of the candidate proteins, SAA1, was identified by 3 groups[61;64;65]. In all published studies, elevated SAA1 concentration correlated with metastasis, poor prognosis and shorter survival[61;64-66], even though different cut-off values were used. Independent studies are needed to substantiate the value of SAA1.

Finally, an 831 tumor tissue microarray study analyzed 15 proteins that are associated with the pVHL and phosphatase and tensin homologue (PTEN) pathways[67]. Surprisingly, while pVHL and phospho-mTOR staining correlated inversely with tumor stage and grade, neither protein correlated with survival. Within the intermediate stage tumors (pT2 and pT3), tumors with p27 and CAIX expression associated with improved outcome. This study suggests that the dysregulation of several independent pathways are crucial for tumor progression, corroborating the sequencing study by Dalglish, et al.[29].

MicroRNA, 21-23 nucleotide segments of single-stranded non-coding RNA, have now been implicated in tumorigenesis of many cancers, even being identified as potential prognostic biomarkers in several of these (reviewed in [68]). The aberrant expression of these noncoding RNAs can provide a powerful method of epigenetic tumor regulation, as an individual microRNA can alter the expression of many target genes. In RCC, various studies have identified various individual or panels of microRNAs that are differentially expressed between normal renal tissue and tumor or between histological subtypes[69-76]. The identification of relevant targets of these tumor associated microRNAs are just becoming realized[74]. MicroRNAs can be easily extracted from formalin fixation, paraffin embedded tissue, and blood. The ability to easily use non-invasive measures to identify a stable target makes microRNAs a very attractive biomarker for diagnostic, prognostic, and predictive purposes.

A large number of potential biomarkers have emerged from all these gene expression studies. Encouragingly, trends are beginning to emerge between studies. The next important step will be bringing these potential biomarkers and biomarker profiles to the clinical arena. 


\section{Targeted therapies in RCC}

The increased understanding of the fundamental disease biology of RCC has been translated into the development of therapies with inhibitory activity against the implicated pathways, particularly the VEGF and mTOR pathways. A number of tyrosine kinase inhibitors (TKI) have now been registered for treatment of metastatic RCC (mRCC) (sunitinib, sorafenib, pazopanib) and more TKI (e.g. axitinib, tivozanib) are being developed. The rapid and simultaneous emergence of several active compounds has far outpaced the ability to critically understand precise mechanisms of response and resistance[77].

Surprisingly, the TKI were clinically implemented with very few preceding pre-clinical studies. For example, the cross-reactivity of TKI with non-target (non-VEGF-receptor) TK[78] was established after clinical implementation and preclinical studies in various animal models demonstrated stabilization or regression of xenografted tumors (mostly in non-RCC models). The rationale to study this new category of drugs in RCC patients was based on theoretical considerations that these TKI attacked pathways essential in RCC biology and, therefore, might be appropriate new drugs for RCC therapy. Indeed, the effects of TKI in RCC patients are impressive, with objective response rates as high as $45 \%$ (reviewed by e.g., Rini et al. [79]), but treatment is often accompanied by many side effects requiring dose reduction or cessation of treatment.

TKI treatment of RCC patients leads to a massive destruction of the tumor vasculature with concomitant tumor necrosis. Whether RCC cells themselves are targeted remains uncertain[80]. At pharmacological relevant doses no effect on tumor cells was observed[80] and there is evidence that tumor co-option occurs, i.e., tumor growth along larger mature vessels, permitting tumors to escape TKI treatment. Additionally, resistance to existing VEGF blocking agents may include upregulation of HIF- and/or non-HIF-mediated angiogenic proteins or inadequate target inhibition. mTOR therapy resistance may involve a compensatory increase in upstream elements leading to HIF production[77].

Obviously, predictive biomarkers for response to TKI in mRCC patients are urgently needed, and some have been described. Serum from patients with clinical response or progression was screened by cytokine arrays to discover that TNF-alpha and MMP-9 levels remained low in responders[81]. Additionally, high levels of these proteins in the serum correlated with decreased overall survival. In another study, low serum levels of sVEGFR-3 and VEGF-C corresponded with longer progression free survival (PFS) and objective response rate in bevacizumab-refractory $\mathrm{mRCC}[82]$. A third study suggested that large changes in serum VEGF, sVEGFR-2 and sVEGFR-3 levels corresponded with tumor response[83], and a fourth study found a correlation between fold-increase of serum VEGF and clinical benefit[84]. All of these potential predictive biomarkers require external validation in larger sample sizes, but suggest that serum may prove to contain cogent markers of survival and response. 


\section{RCC and the immune system}

There is increasing evidence that TKI treatment leads to alterations of the immune status of RCC patients[85;86]. Sunitinib can reverse myeloid-derived suppressor cell induced immune suppression, but other studies indicate that Sunitinib can inhibit the proliferation of primary human T cells from normal healthy volunteers as well as from RCC patients[87]. Moreover, sunitinib treatment appears to reverse Th1 suppression and impairs NK function. Similarly, sorafenib treatment impairs NK activity and cytotoxicity at pharmacological levels[85]. Also, sorafenib treatment leads to a decrease of Treg in primary lesions and Treg levels decrease to normal levels after sorafenib treatment. Whether the immune component is important and might be used to our advantage in designing combination therapies is an uncharted field[86].

It is important to realize that RCC tumors develop in immune competent hosts and that these tumors have escaped from immune surveillance and immune editing leading to tumor cells that are resistant to immune-system mediated destruction[88]. Nevertheless, to date, immunotherapy is the only treatment that can consistently induce durable complete clinical responses in $\mathrm{mRCC}[89]$.

Several studies have demonstrated the ability of tumor infiltrating lymphocytes (TIL) to induce tumor response in mRCC with objective response rates between 0 and $25 \%$, with concomitant infusion of IL-2[90-95]. At UCLA, patients with largely advanced and metastatic disease received a combination of TIL/CD8+ and IL-2. Overall, $9.1 \%$ of patients achieved CR while $25.5 \%$ had a PR showing the potential of TIL in mRCC [94]. Taken together these studies demonstrated the need of using highly selective and specific activation methods of effector cells in order to achieve a meaningful antitumor immune response. Unlike melanoma, where specific T-cell clones against well-defined tumor epitopes can be frequently generated, T-cell clones that specifically recognize kidney cancer tumor antigens are hard to generate. The proof of concept of isolating these clones and successfully treat patients with $\mathrm{mRCC}$ has however been well established. On the other hand, given the in vitro work needed to isolate TIL, this approach still needs to prove that it induces better clinical responses than HD-IL2 alone.

Side studies of clinical trials with dendritic cells loaded with cell lysates, peptides, or RNA or Treg depletion have demonstrated the induction of specific $\mathrm{T}$ cell responses, but no clear correlation between clinical benefit and the occurrence of a immune reaction was found[96;97]. There is evidence that various factor hamper an anti-tumor response: defective CD8 signaling, a Th2-bias, and elevated levels of gangliosides from $\mathrm{T}$ cells are associated with $\mathrm{T}$ cell dysfunction[98;99]. Basic research aimed at understanding the relation between RCC and immune cells have revealed an increasingly complex picture with many players. Cross-talk between RCC and dendritic cells (DC), Treg, CD4+, CD8+, NK-cells, $\gamma \delta \mathrm{T}$ cells, NK-like T cells, and Myeloid Derived Suppressor Cells, have been described[100]. The plasticity of cells from the immune system is extraordinary and the tumor milieu plays a pivotal role and can greatly influence the outcome. 
In recent studies, efforts were poised at gene-modified T-cells[101] and multimodality immune-based strategies[102]. Gene-modified T cells in melanoma has shown interesting results with two CR [103]. For RCC, infusion of gene-modified T cells with CAIX specificity lead to liver toxicity, probably due to destruction of bile epithelial cells that also express CAIX[101]. Although this demonstrated that the gene-modified did exert the desired specificity, the observed toxicity also highlights the potential problems of this approach: extraordinary tumor specificity appears to be of utmost importance. In the multi-modality immune-based strategy the CA9 and GMCSF genes were inserted in an adenovirus genome to infect DC which allowed the expression of the GMCSF/CA9 fusion protein[102]. Overexpression of the fusion protein in DC through adenoviral infection CA9 specific $\mathrm{T}$ cells could be generated with toxicity against RCC. Hence, this new strategy combines many immunotherapy approaches: 1) the immunostimulatory effects of cytokines; 2) the vaccine capabilities of DC and; 3) the specific antitumor activity generated by tumor antigen gene delivery in APC. Indeed, the CA9-GMCSF/DC based vaccine is an example of the new multimodality immune-based strategies that may enhance the well-established potentials of immunotherapy in RCC.

The effectiveness of tumor vaccines has been shown in many animal models. However, translation to the clinic has proven difficult, possibly because in these model systems naturally occurring tumors have not been studied, thereby avoiding tumor surveillance and tumor editing. Thus, the concept is tested in immune competent hosts that are vaccinated with peptides or tumor homogenates and challenged with viable tumor cells or, alternatively, vaccination strategies are tested in animals with established tumors. Initial tumor vaccines were based on total tumor cell lysates that were injected to the patients (autologous tumor cell vaccines). However, new strategies using genetically modified tumor cells, antigen presenting cells (APC) or tumor specific peptides have been developed to increase the specificity of the response. Two phase-III clinical trials that have used autologous cell lysate or peptides to prevent recurrence in high-risk RCC patients have been published[104;105]. Jocham et al. have reported a statistically significant increase in 5-year PFS (77.4 vs 67.8\%, $\mathrm{p}=0.0204$ ) for the vaccine group in high-risk non-metastatic RCC patients. More recently, Wood et al. published a similar study in high-risk non-metastatic patients using heat shock protein derived peptide vaccines and did not observe a statistical difference in PFS $(\mathrm{p}=0.51)$. However, secondary analysis did show an almost statistically significant PFS survival when only stage I and II patients where included ( $\mathrm{p}=0.056$ ). Therefore, vaccine approaches show great promise in preventing recurrence after nephrectomy but the subgroups of patients that would beneficiate from such therapy still need to be determined.

\section{Genetic factors and RCC}

Epidemiological studies have conclusively identified three risk factors for the development of RCC: hypertension, obesity and smoking[106-108]. Furthermore, there is evidence that genetic factors influence susceptibility to RCC; for instance, the life-time risk increases approximately two-fold for those with a first-degree relative with RCC[109]. Thus far, candidate gene studies have not yielded notable candidate genes. In a recent genome-wide association study (GWAS) of RCC three susceptibility loci on chromosomes 2p21 (EPAS1), 11q13.3 and 12q24.31 (SCARB1) were identified (Purdue et al, submitted). The findings 
from the GWAS provided further evidence that EPAS1 (HIF2a) is a key gene in RCC development, but additional studies are needed to identify the functionally relevant common variants associated with increased risk.

Up to now little attention has been paid to inter-ethnic variability or individual differences, whereas this is an important aspect in the current TKI era. Patients of afro-american descent have higher incidence rates and lower survival rates compared to all other races, also when diagnosed with localized disease. In contrast, Asian/Pacific Islander patients have lower incidence rates and higher survival rates than all the other ethnicities[110]. Furthermore, response to treatment and frequency of severe toxicity is related to ethnic origin, most likely due to different pharmacokinetics and not the genetic nature of the disease. Sunitinib, sorafenib and pazopanib have been associated with significant toxicity profiles which vary widely. Higher toxicities during cytotoxic chemotherapy have been reported in patients enrolled Japanese trials compared to patients in American or European trials[111]. Ethnic differences in hematological toxicity have been attributed to the varying activities of drug metabolizing enzymes and transporters that are mainly associated with polymorphisms in the promoter and coding regions of these enzymes[111]. In a phase II study assessing the efficacy and safety of sunitinib in Japanese patients, the incidence of hematological adverse events was numerically higher than those previously reported in western trials, however the AUC values for sunitinib were similar in both groups[112].

In the only pharmacogenetic study published until now, 31 single nucleotide polymorphisms in 12 candidate genes, together with several non-genetic variants, were analyzed for a possible association with toxicity[113]. Encouragingly, particular haplotypes (most notably by polymorphisms in CYP1A1) could be correlated to sunitinib-related toxicity. Because race-related differences in the frequency distribution of four genetic polymorphisms in the CYP1A1 P450 enzyme genes have been identified between Japanese and Caucasian populations, this may partly explain the inter-ethnic differences observed[114].

\section{Conclusions}

In the last decade, great strides have been made in the understanding of molecular mechanisms underlying renal cell carcinoma patients. The state-of-the-art has clearly led this field to the enviable position of having a range of molecularly targeted therapies. Nevertheless, despite the clear improvement in the therapeutic options for mRCC patients, therapies targeting the tumor cells themselves are highly desirable. Better models, closer resembling the natural course of renal cancer are needed. It is foreseen that through integration of various high-throughput platforms personalized cancer treatment for renal cell carcinoma patients is possible. There are further improvements expected on the horizon: recent effort have made progress toward using formalin-fixed paraffin-embedded tissues for molecular analyses (including DNA and RNA recovery), which will permit studies on enormous archives of existing specimens [115] including metastatic lesions, a hitherto understudied area; mature profiles of protein and nucleic acid biomarkers will help us to define the spectrum of tumors that lie under the umbrella of ccRCC; and a future unmapped territory of genetic mutations to explore that may provide more tools and answers to the 
questions we ask. There is great hope for the future of renal cell carcinoma treatment, and it will be exciting to see what new advances will be made in the decade to come.

\section{Reference List}

1. Cancer facts and figures 2009. Atlanta, GA: American Cancer Society, Inc; 2009.

2. Ferlay J, Autier P, Boniol M, Heanue M, Colombet M, Boyle P. Estimates of the cancer incidence and mortality in Europe in 2006. Ann Oncol. 2007; 18:581-92. [PubMed: 17287242]

3. Thoenes W, Storkel S, Rumpelt HJ. Histopathology and classification of renal cell tumors (adenomas, oncocytomas and carcinomas). The basic cytological and histopathological elements and their use for diagnostics. Pathol Res Pract. 1986; 181:125-43. [PubMed: 3737468]

4. Kovacs G, Akhtar M, Beckwith BJ, et al. The Heidelberg classification of renal cell tumours. J Pathol. 1997; 183:131-3. [PubMed: 9390023]

5. Argani P, Ladanyi M. Translocation carcinomas of the kidney. Clin Lab Med. 2005; 25:363-78. [PubMed: 15848741]

6. Medendorp K, van Groningen JJ, Schepens M, et al. Molecular mechanisms underlying the MiT translocation subgroup of renal cell carcinomas. Cytogenet Genome Res. 2007; 118:157-65. [PubMed: 18000366]

7. Yang G, Breyer BN, Weiss DA, MacLennan GT. Mucinous tubular and spindle cell carcinoma of the kidney. J Urol. 2010; 183:738-9. [PubMed: 20022029]

8. Srigley JR, Delahunt B. Uncommon and recently described renal carcinomas. Mod Pathol. 2009; 22(Suppl 2):S2-S23. [PubMed: 19494850]

9. Latif F, Tory K, Gnarra J, et al. Identification of the von Hippel-Lindau disease tumor suppressor gene. Science. 1993; 260:1317-20. [PubMed: 8493574]

10. Foster K, Prowse A, van den BA, et al. Somatic mutations of the von Hippel-Lindau disease tumour suppressor gene in non-familial clear cell renal carcinoma. Hum Mol Genet. 1994; 3:2169-73. [PubMed: 7881415]

11. Gnarra JR, Tory K, Weng Y, et al. Mutations of the VHL tumour suppressor gene in renal carcinoma. Nat Genet. 1994; 7:85-90. [PubMed: 7915601]

12. Herman JG, Latif F, Weng Y, et al. Silencing of the VHL tumor-suppressor gene by DNA methylation in renal carcinoma. Proc Natl Acad Sci U S A. 1994; 91:9700-4. [PubMed: 7937876]

13. Shuin T, Kondo K, Torigoe $S$, et al. Frequent somatic mutations and loss of heterozygosity of the von Hippel-Lindau tumor suppressor gene in primary human renal cell carcinomas. Cancer Res. 1994; 54:2852-5. [PubMed: 8187067]

14. Cockman ME, Masson N, Mole DR, et al. Hypoxia inducible factor-alpha binding and ubiquitylation by the von Hippel-Lindau tumor suppressor protein. J Biol Chem. 2000; 275:25733-41. [PubMed: 10823831]

15. Kamura T, Sato S, Iwai K, Czyzyk-Krzeska M, Conaway RC, Conaway JW. Activation of HIF1alpha ubiquitination by a reconstituted von Hippel-Lindau (VHL) tumor suppressor complex. Proc Natl Acad Sci U S A. 2000; 97:10430-5. [PubMed: 10973499]

16. Maxwell PH, Wiesener MS, Chang GW, et al. The tumour suppressor protein VHL targets hypoxia-inducible factors for oxygen-dependent proteolysis. Nature. 1999; 399:271-5. [PubMed: 10353251]

17. Ohh M, Park CW, Ivan M, et al. Ubiquitination of hypoxia-inducible factor requires direct binding to the beta-domain of the von Hippel-Lindau protein. Nat Cell Biol. 2000; 2:423-7. [PubMed: 10878807]

18. Tanimoto K, Makino Y, Pereira T, Poellinger L. Mechanism of regulation of the hypoxia-inducible factor-1 alpha by the von Hippel-Lindau tumor suppressor protein. EMBO J. 2000; 19:4298-309. [PubMed: 10944113]

19. Maynard MA, Qi H, Chung J, et al. Multiple splice variants of the human HIF-3 alpha locus are targets of the von Hippel-Lindau E3 ubiquitin ligase complex. J Biol Chem. 2003; 278:11032-40. [PubMed: 12538644] 
20. Iliopoulos O, Kibel A, Gray S, Kaelin WG Jr. Tumour suppression by the human von HippelLindau gene product. Nat Med. 1995; 1:822-6. [PubMed: 7585187]

21. Kondo K, Klco J, Nakamura E, Lechpammer M, Kaelin WG Jr. Inhibition of HIF is necessary for tumor suppression by the von Hippel-Lindau protein. Cancer Cell. 2002; 1:237-46. [PubMed: 12086860]

22. Linehan WM, Bratslavsky G, Pinto PA, et al. Molecular diagnosis and therapy of kidney cancer. Annu Rev Med. 2010; 61:329-43. [PubMed: 20059341]

23. Tomlinson IP, Alam NA, Rowan AJ, et al. Germline mutations in FH predispose to dominantly inherited uterine fibroids, skin leiomyomata and papillary renal cell cancer. Nat Genet. 2002; 30:406-10. [PubMed: 11865300]

24. Hasumi Y, Baba M, Ajima R, et al. Homozygous loss of BHD causes early embryonic lethality and kidney tumor development with activation of mTORC1 and mTORC2. Proc Natl Acad Sci U S A. 2009; 106:18722-7. [PubMed: 19850877]

25. Lee CM, Hickey MM, Sanford CA, et al. VHL Type 2B gene mutation moderates HIF dosage in vitro and in vivo. Oncogene. 2009; 28:1694-705. [PubMed: 19252526]

26. Rathmell WK, Hickey MM, Bezman NA, Chmielecki CA, Carraway NC, Simon MC. In vitro and in vivo models analyzing von Hippel-Lindau disease-specific mutations. Cancer Res. 2004; 64:8595-603. [PubMed: 15574766]

27. Gordan JD, Lal P, Dondeti VR, et al. HIF-alpha effects on c-Myc distinguish two subtypes of sporadic VHL-deficient clear cell renal carcinoma. Cancer Cell. 2008; 14:435-46. [PubMed: 19061835]

28. Nogueira M, Kim HL. Molecular markers for predicting prognosis of renal cell carcinoma. Urol Oncol. 2008; 26:113-24. [PubMed: 18312928]

29. Dalgliesh GL, Furge K, Greenman C, et al. Systematic sequencing of renal carcinoma reveals inactivation of histone modifying genes. Nature. 2010; 463:360-3. [PubMed: 20054297]

30. Beroukhim R, Brunet JP, Di NA, et al. Patterns of gene expression and copy-number alterations in von-hippel lindau disease-associated and sporadic clear cell carcinoma of the kidney. Cancer Res. 2009; 69:4674-81. [PubMed: 19470766]

31. Furge KA, Lucas KA, Takahashi M, et al. Robust classification of renal cell carcinoma based on gene expression data and predicted cytogenetic profiles. Cancer Res. 2004; 64:4117-21. [PubMed: 15205321]

32. Klatte T, Rao PN, de MM, et al. Cytogenetic profile predicts prognosis of patients with clear cell renal cell carcinoma. J Clin Oncol. 2009; 27:746-53. [PubMed: 19124809]

33. Meloni-Ehrig AM. Renal cancer: cytogenetic and molecular genetic aspects. Am J Med Genet. 2002; 115:164-72. [PubMed: 12407697]

34. Sultmann H, von HA, Huber W, et al. Gene expression in kidney cancer is associated with cytogenetic abnormalities, metastasis formation, and patient survival. Clin Cancer Res. 2005; 11:646-55. [PubMed: 15701852]

35. Kapitsinou PP, Haase VH. The VHL tumor suppressor and HIF: insights from genetic studies in mice. Cell Death Differ. 2008; 15:650-9. [PubMed: 18219317]

36. van RE, Voest EE, Logister I, et al. von Hippel-Lindau tumor suppressor mutants faithfully model pathological hypoxia-driven angiogenesis and vascular retinopathies in zebrafish. Dis Model Mech. 2010; 3:343-53. [PubMed: 20335444]

37. Cowey CL, Rathmell WK. VHL gene mutations in renal cell carcinoma: role as a biomarker of disease outcome and drug efficacy. Curr Oncol Rep. 2009; 11:94-101. [PubMed: 19216840]

38. Gordan JD, Simon MC. Hypoxia-inducible factors: central regulators of the tumor phenotype. Curr Opin Genet Dev. 2007; 17:71-7. [PubMed: 17208433]

39. Takahashi M, Rhodes DR, Furge KA, et al. Gene expression profiling of clear cell renal cell carcinoma: gene identification and prognostic classification. Proc Natl Acad Sci U S A. 2001; 98:9754-9. [PubMed: 11493696]

40. Vasselli JR, Shih JH, Iyengar SR, et al. Predicting survival in patients with metastatic kidney cancer by gene-expression profiling in the primary tumor. Proc Natl Acad Sci U S A. 2003; 100:6958-63. [PubMed: 12777628] 
41. Shioi K, Komiya A, Hattori K, et al. Vascular cell adhesion molecule 1 predicts cancer-free survival in clear cell renal carcinoma patients. Clin Cancer Res. 2006; 12:7339-46. [PubMed: 17189405]

42. Yao M, Huang Y, Shioi K, et al. A three-gene expression signature model to predict clinical outcome of clear cell renal carcinoma. Int J Cancer. 2008; 123:1126-32. [PubMed: 18546273]

43. Jones J, Otu H, Spentzos D, et al. Gene signatures of progression and metastasis in renal cell cancer. Clin Cancer Res. 2005; 11:5730-9. [PubMed: 16115910]

44. Kosari F, Parker AS, Kube DM, et al. Clear cell renal cell carcinoma: gene expression analyses identify a potential signature for tumor aggressiveness. Clin Cancer Res. 2005; 11:5128-39. [PubMed: 16033827]

45. Parker AS, Kosari F, Lohse CM, et al. High expression levels of survivin protein independently predict a poor outcome for patients who undergo surgery for clear cell renal cell carcinoma. Cancer. 2006; 107:37-45. [PubMed: 16736510]

46. Parker AS, Leibovich BC, Lohse CM, et al. Development and evaluation of BioScore: a biomarker panel to enhance prognostic algorithms for clear cell renal cell carcinoma. Cancer. 2009; 115:2092-103. [PubMed: 19296514]

47. Zhao H, Ljungberg B, Grankvist K, Rasmuson T, Tibshirani R, Brooks JD. Gene expression profiling predicts survival in conventional renal cell carcinoma. PLoS Med. 2006; 3:e13. [PubMed: 16318415]

48. Zhao H, Zongming M, Tibshirani R, Higgins JP, Ljungberg B, Brooks JD. Alteration of gene expression signatures of cortical differentiation and wound response in lethal clear cell renal cell carcinomas. PLoS One. 2009; 4:e6039. [PubMed: 19557179]

49. Skubitz KM, Zimmermann W, Kammerer R, Pambuccian S, Skubitz AP. Differential gene expression identifies subgroups of renal cell carcinoma. J Lab Clin Med. 2006; 147:250-67. [PubMed: 16697773]

50. Brannon AR, Reddy AK, Seiler MW, Rathmell WK. Molecular stratification of clear cell renal cell carcinoma by consensus clustering revelas distinct subtypes and survival patterns. Genes and Cancer. 2010

51. Wuttig D, Baier B, Fuessel S, et al. Gene signatures of pulmonary metastases of renal cell carcinoma reflect the disease-free interval and the number of metastases per patient. Int J Cancer. 2009; 125:474-82. [PubMed: 19391132]

52. Schips L, Dalpiaz O, Lipsky K, et al. Serum levels of vascular endothelial growth factor (VEGF) and endostatin in renal cell carcinoma patients compared to a control group. Eur Urol. 2007; 51:168-73. [PubMed: 16844285]

53. Kushlinsky NE, Trapeznikova MF, Gershtein ES, Glibin PA, Kazantceva IA, Kilichbekov MB. Vascular endothelial growth factor and its type 2 receptor in tumors and serum of patients with renal cancer. Bull Exp Biol Med. 2008; 145:744-7. [PubMed: 19110567]

54. Zhou GX, Ireland J, Rayman P, Finke J, Zhou M. Quantification of carbonic anhydrase IX expression in serum and tissue of renal cell carcinoma patients using enzyme-linked immunosorbent assay: prognostic and diagnostic potentials. Urology. 2010; 75:257-61. [PubMed: 19963243]

55. Li G, Feng G, Gentil-Perret A, Genin C, Tostain J. Serum carbonic anhydrase 9 level is associated with postoperative recurrence of conventional renal cell cancer. J Urol. 2008; 180:510-3. [PubMed: 18550116]

56. Sarkissian G, Fergelot P, Lamy PJ, et al. Identification of pro-MMP-7 as a serum marker for renal cell carcinoma by use of proteomic analysis. Clin Chem. 2008; 54:574-81. [PubMed: 18202161]

57. Horstmann M, Merseburger AS, von der HE, et al. Correlation of bFGF expression in renal cell cancer with clinical and histopathological features by tissue microarray analysis and measurement of serum levels. J Cancer Res Clin Oncol. 2005; 131:715-22. [PubMed: 16080018]

58. Negrier S, Perol D, Menetrier-Caux C, et al. Interleukin-6, interleukin-10, and vascular endothelial growth factor in metastatic renal cell carcinoma: prognostic value of interleukin-6--from the Groupe Francais d'Immunotherapie. J Clin Oncol. 2004; 22:2371-8. [PubMed: 15197198]

59. Kimura M, Tomita Y, Imai T, et al. Significance of serum-soluble CD95 (Fas/APO-1) on prognosis in renal cell cancer patients. Br J Cancer. 1999; 80:1648-51. [PubMed: 10408413] 
60. Kamai T, Tomosugi N, Abe H, Arai K, Yoshida K. Increased serum hepcidin-25 level and increased tumor expression of hepcidin mRNA are associated with metastasis of renal cell carcinoma. BMC Cancer. 2009; 9:270. [PubMed: 19656379]

61. Tolson J, Bogumil R, Brunst E, et al. Serum protein profiling by SELDI mass spectrometry: detection of multiple variants of serum amyloid alpha in renal cancer patients. Lab Invest. 2004; 84:845-56. [PubMed: 15107802]

62. Won Y, Song HJ, Kang TW, Kim JJ, Han BD, Lee SW. Pattern analysis of serum proteome distinguishes renal cell carcinoma from other urologic diseases and healthy persons. Proteomics. 2003; 3:2310-6. [PubMed: 14673781]

63. Xu G, Xiang CQ, Lu Y, et al. Application of SELDI-TOF-MS to identify serum biomarkers for renal cell carcinoma. Cancer Lett. 2009; 282:205-13. [PubMed: 19362769]

64. Vermaat JS, van dT I, Mehra N, et al. Two-protein signature of novel serological markers apolipoprotein-A2 and serum amyloid alpha predicts prognosis in patients with metastatic renal cell cancer and improves the currently used prognostic survival models. Ann Oncol. 2009

65. Junker K, von EF, Muller J, Steiner T, Schubert J. Identification of biomarkers and therapeutic targets for renal cell cancer using ProteinChip technology. Urologe A. 2006; 45:305-12. [PubMed: 16491405]

66. Kimura M, Tomita Y, Imai T, et al. Significance of serum amyloid A on the prognosis in patients with renal cell carcinoma. Cancer. 2001; 92:2072-5. [PubMed: 11596022]

67. Dahinden C, Ingold B, Wild $\mathrm{P}$, et al. Mining tissue microarray data to uncover combinations of biomarker expression patterns that improve intermediate staging and grading of clear cell renal cell cancer. Clin Cancer Res. 2010; 16:88-98. [PubMed: 20028743]

68. Cho WC. MicroRNAs: Potential biomarkers for cancer diagnosis, prognosis and targets for therapy. Int J Biochem Cell Biol. 2009

69. Chow TF, Youssef YM, Lianidou E, et al. Differential expression profiling of microRNAs and their potential involvement in renal cell carcinoma pathogenesis. Clin Biochem. 2010; 43:150-8. [PubMed: 19646430]

70. Huang Y, Dai Y, Yang J, et al. Microarray analysis of microRNA expression in renal clear cell carcinoma. Eur J Surg Oncol. 2009; 35:1119-23. [PubMed: 19443172]

71. Juan D, Alexe G, Antes T, et al. Identification of a microRNA panel for clear-cell kidney cancer. Urology. 2010; 75:835-41. [PubMed: 20035975]

72. Jung M, Mollenkopf HJ, Grimm C, et al. MicroRNA profiling of clear cell renal cell cancer identifies a robust signature to define renal malignancy. J Cell Mol Med. 2009; 13:3918-28. [PubMed: 19228262]

73. Liu H, Brannon AR, Reddy AK, et al. Identifying mRNA targets of microRNA dysregulated in cancer: with application to clear cell Renal Cell Carcinoma. BMC Syst Biol. 2010; 4:51. [PubMed: 20420713]

74. Nakada C, Matsuura K, Tsukamoto Y, et al. Genome-wide microRNA expression profiling in renal cell carcinoma: significant down-regulation of miR-141 and miR-200c. J Pathol. 2008; 216:41827. [PubMed: 18925646]

75. Petillo D, Kort EJ, Anema J, Furge KA, Yang XJ, Teh BT. MicroRNA profiling of human kidney cancer subtypes. Int J Oncol. 2009; 35:109-14. [PubMed: 19513557]

76. Gottardo F, Liu CG, Ferracin M, et al. Micro-RNA profiling in kidney and bladder cancers. Urol Oncol. 2007; 25:387-92. [PubMed: 17826655]

77. Rini BI. Metastatic renal cell carcinoma: many treatment options, one patient. J Clin Oncol. 2009; 27:3225-34. [PubMed: 19470934]

78. Fabian MA, Biggs WH III, Treiber DK, et al. A small molecule-kinase interaction map for clinical kinase inhibitors. Nat Biotechnol. 2005; 23:329-36. [PubMed: 15711537]

79. Rini BI, Campbell SC, Escudier B. Renal cell carcinoma. Lancet. 2009; 373:1119-32. [PubMed: 19269025]

80. Huang D, Ding Y, Li Y, et al. Sunitinib acts primarily on tumor endothelium rather than tumor cells to inhibit the growth of renal cell carcinoma. Cancer Res. 2010; 70:1053-62. [PubMed: 20103629] 
81. Perez-Gracia JL, Prior C, Guillen-Grima F, et al. Identification of TNF-alpha and MMP-9 as potential baseline predictive serum markers of sunitinib activity in patients with renal cell carcinoma using a human cytokine array. Br J Cancer. 2009; 101:1876-83. [PubMed: 19904265]

82. Rini BI, Michaelson MD, Rosenberg JE, et al. Antitumor activity and biomarker analysis of sunitinib in patients with bevacizumab-refractory metastatic renal cell carcinoma. J Clin Oncol. 2008; 26:3743-8. [PubMed: 18669461]

83. DePrimo SE, Bello C. Surrogate biomarkers in evaluating response to anti-angiogenic agents: focus on sunitinib. Ann Oncol. 2007; 18(Suppl 10):x11-x19. [PubMed: 17761718]

84. Kontovinis LF, Papazisis KT, Touplikioti P, Andreadis C, Mouratidou D, Kortsaris AH. Sunitinib treatment for patients with clear-cell metastatic renal cell carcinoma: clinical outcomes and plasma angiogenesis markers. BMC Cancer. 2009; 9:82. [PubMed: 19284623]

85. Krusch M, Salih J, Schlicke M, et al. The kinase inhibitors sunitinib and sorafenib differentially affect NK cell antitumor reactivity in vitro. J Immunol. 2009; 183:8286-94. [PubMed: 20007592]

86. Seliger B, Massa C, Rini B, Ko J, Finke J. Antitumour and immune-adjuvant activities of proteintyrosine kinase inhibitors. Trends Mol Med. 2010; 16:184-92. [PubMed: 20304705]

87. Gu Y, Zhao W, Meng F, et al. Sunitinib impairs the proliferation and function of human peripheral $\mathrm{T}$ cell and prevents T-cell-mediated immune response in mice. Clin Immunol. 2010; 135:55-62. [PubMed: 20015695]

88. Swann JB, Smyth MJ. Immune surveillance of tumors. J Clin Invest. 2007; 117:1137-46. [PubMed: 17476343]

89. McDermott DF, Ghebremichael M, Signoretti S, et al. The high-dose aldesleukin (HD IL-2) Select trial in patients with metastatic renal cell carcinoma (mRCC): Preliminary assessment of clinical benefit. 2010 Ref Type: Abstract.

90. Kradin RL, Kurnick JT, Lazarus DS, et al. Tumour-infiltrating lymphocytes and interleukin-2 in treatment of advanced cancer. Lancet. 1989; 1:577-80. [PubMed: 2564111]

91. Bukowski RM, Sharfman W, Murthy S, et al. Clinical results and characterization of tumorinfiltrating lymphocytes with or without recombinant interleukin 2 in human metastatic renal cell carcinoma. Cancer Res. 1991; 51:4199-205. [PubMed: 1868441]

92. Dillman R, Schiltz P, DePriest C, et al. Tumor-infiltrating lymphocytes and interleukin-2: dose and schedules of administration in the treatment of metastatic cancer. Cancer Biother Radiopharm. 2004; 19:730-7. [PubMed: 15665620]

93. Goedegebuure PS, Douville LM, Li H, et al. Adoptive immunotherapy with tumor-infiltrating lymphocytes and interleukin-2 in patients with metastatic malignant melanoma and renal cell carcinoma: a pilot study. J Clin Oncol. 1995; 13:1939-49. [PubMed: 7636534]

94. Figlin RA, Thompson JA, Bukowski RM, et al. Multicenter, randomized, phase III trial of CD8(+) tumor-infiltrating lymphocytes in combination with recombinant interleukin-2 in metastatic renal cell carcinoma. J Clin Oncol. 1999; 17:2521-9. [PubMed: 10561318]

95. Belldegrun A, Tso CL, Kaboo R, et al. Natural immune reactivity-associated therapeutic response in patients with metastatic renal cell carcinoma receiving tumor-infiltrating lymphocytes and interleukin-2-based therapy. J Immunother Emphasis Tumor Immunol. 1996; 19:149-61. [PubMed: 8732698]

96. Su Z, Dannull J, Heiser A, et al. Immunological and clinical responses in metastatic renal cancer patients vaccinated with tumor RNA-transfected dendritic cells. Cancer Res. 2003; 63:2127-33. [PubMed: 12727829]

97. Dannull J, Su Z, Rizzieri D, et al. Enhancement of vaccine-mediated antitumor immunity in cancer patients after depletion of regulatory T cells. J Clin Invest. 2005; 115:3623-33. [PubMed: 16308572]

98. Ng CS, Novick AC, Tannenbaum CS, Bukowski RM, Finke JH. Mechanisms of immune evasion by renal cell carcinoma: tumor-induced T-lymphocyte apoptosis and NFkappaB suppression. Urology. 2002; 59:9-14. [PubMed: 11796271]

99. Uzzo RG, Rayman P, Kolenko V, et al. Renal cell carcinoma-derived gangliosides suppress nuclear factor-kappaB activation in T cells. J Clin Invest. 1999; 104:769-76. [PubMed: 10491412] 
100. Geiger C, Nossner E, Frankenberger B, Falk CS, Pohla H, Schendel DJ. Harnessing innate and adaptive immunity for adoptive cell therapy of renal cell carcinoma. J Mol Med. 2009; 87:595612. [PubMed: 19271159]

101. Lamers CH, Sleijfer S, Vulto AG, et al. Treatment of metastatic renal cell carcinoma with autologous T-lymphocytes genetically retargeted against carbonic anhydrase IX: first clinical experience. J Clin Oncol. 2006; 24:e20-e22. [PubMed: 16648493]

102. Hernandez JM, Bui MH, Han KR, et al. Novel kidney cancer immunotherapy based on the granulocyte-macrophage colony-stimulating factor and carbonic anhydrase IX fusion gene. Clin Cancer Res. 2003; 9:1906-16. [PubMed: 12738749]

103. Morgan RA, Dudley ME, Wunderlich JR, et al. Cancer regression in patients after transfer of genetically engineered lymphocytes. Science. 2006; 314:126-9. [PubMed: 16946036]

104. Jocham D, Richter A, Hoffmann L, et al. Adjuvant autologous renal tumour cell vaccine and risk of tumour progression in patients with renal-cell carcinoma after radical nephrectomy: phase III, randomised controlled trial. Lancet. 2004; 363:594-9. [PubMed: 14987883]

105. Wood C, Srivastava P, Bukowski R, et al. An adjuvant autologous therapeutic vaccine (HSPPC-96; vitespen) versus observation alone for patients at high risk of recurrence after nephrectomy for renal cell carcinoma: a multicentre, open-label, randomised phase III trial. Lancet. 2008; 372:145-54. [PubMed: 18602688]

106. Laber DA. Risk factors, classification, and staging of renal cell cancer. Med Oncol. 2006; 23:44354. [PubMed: 17303902]

107. Lipworth L, Tarone RE, McLaughlin JK. The epidemiology of renal cell carcinoma. J Urol. 2006; 176:2353-8. [PubMed: 17085101]

108. Chow WH, Dong LM, Devesa SS. Epidemiology and risk factors for kidney cancer. Nat Rev Urol. 2010; 7:245-57. [PubMed: 20448658]

109. Hung RJ, Moore L, Boffetta P, et al. Family history and the risk of kidney cancer: a multicenter case-control study in Central Europe. Cancer Epidemiol Biomarkers Prev. 2007; 16:1287-90. [PubMed: 17548699]

110. Stafford HS, Saltzstein SL, Shimasaki S, Sanders C, Downs TM, Sadler GR. Racial/ethnic and gender disparities in renal cell carcinoma incidence and survival. J Urol. 2008; 179:1704-8. [PubMed: 18343443]

111. Sekine I, Yamamoto N, Nishio K, Saijo N. Emerging ethnic differences in lung cancer therapy. $\mathrm{Br}$ J Cancer. 2008; 99:1757-62. [PubMed: 18985035]

112. Uemura H, Shinohara N, Yuasa T, et al. A phase II study of sunitinib in Japanese patients with metastatic renal cell carcinoma: insights into the treatment, efficacy and safety. Jpn J Clin Oncol. 2010; 40:194-202. [PubMed: 19897852]

113. van Erp N, Mathijssen RH, van der Veldt AA, et al. Pharmacogenetic pathway analysis for determination of sunitinib-induced toxicity. J Clin Oncol (Meeting Abstracts). 2009; 27:5006.

114. Shimada T, Yamazaki H, Mimura M, Inui Y, Guengerich FP. Interindividual variations in human liver cytochrome P-450 enzymes involved in the oxidation of drugs, carcinogens and toxic chemicals: studies with liver microsomes of 30 Japanese and 30 Caucasians. J Pharmacol Exp Ther. 1994; 270:414-23. [PubMed: 8035341]

115. Huang WY, Sheehy TM, Moore LE, Hsing AW, Purdue MP. Simultaneous recovery of DNA and RNA from formalin-fixed paraffin-embedded tissue and application in epidemiologic studies. Cancer Epidemiol Biomarkers Prev. 2010; 19:973-7. [PubMed: 20332269]

116. Brannon AR, Rathmell WK. Renal cell carcinoma: where will the state-of-the-art lead us? Curr Oncol Rep. 2010; 12:193-201. [PubMed: 20425079]

117. Jones J, Otu H, Spentzos D, et al. Gene signatures of progression and metastasis in renal cell cancer. Clin Cancer Res. 2005; 11:5730-9. [PubMed: 16115910]

118. Kosari F, Parker AS, Kube DM, et al. Clear cell renal cell carcinoma: gene expression analyses identify a potential signature for tumor aggressiveness. Clin Cancer Res. 2005; 11:5128-39. [PubMed: 16033827]

119. Yao M, Huang Y, Shioi K, et al. A three-gene expression signature model to predict clinical outcome of clear cell renal carcinoma. Int J Cancer. 2008; 123:1126-32. [PubMed: 18546273] 


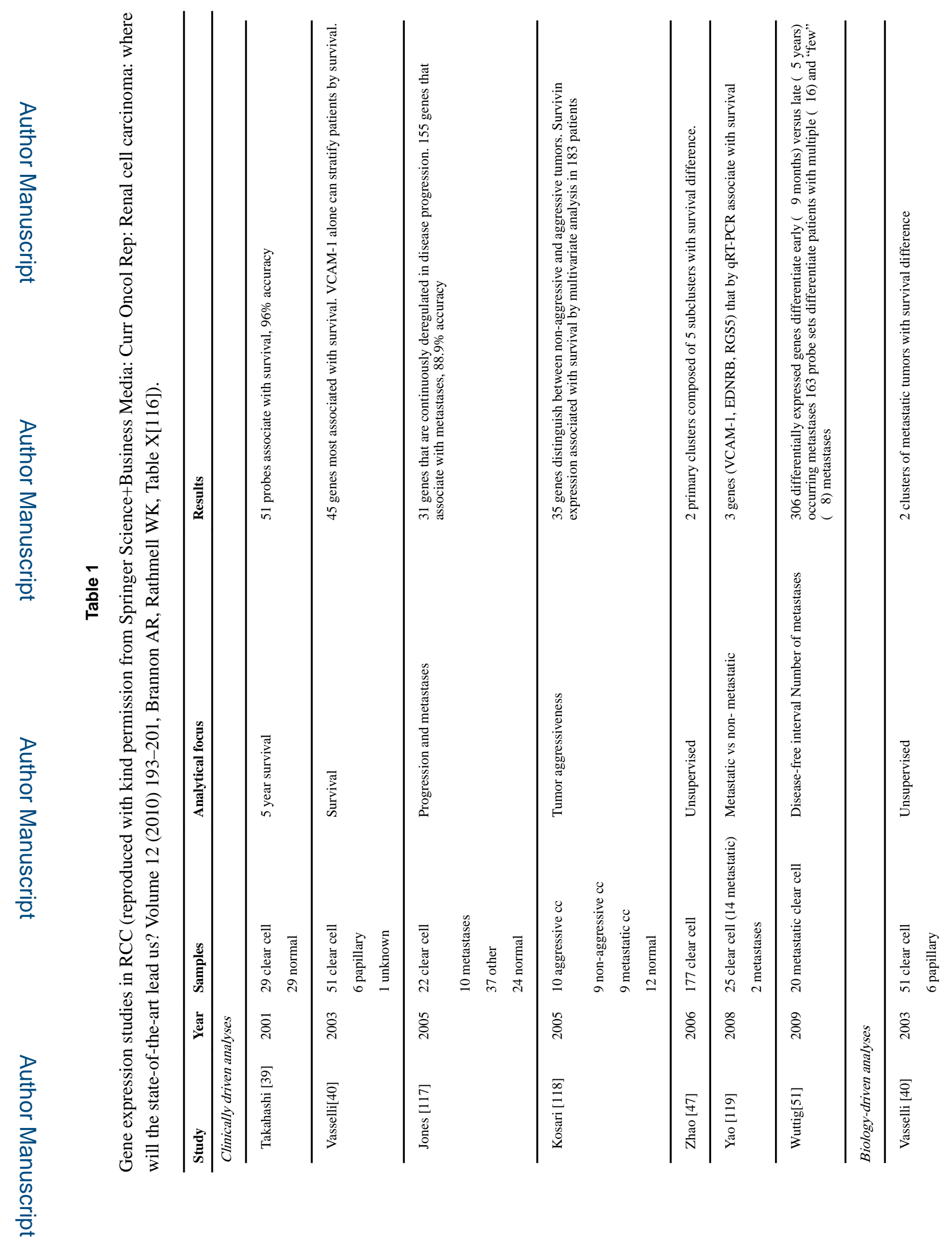

Eur Urol. Author manuscript; available in PMC 2016 May 23. 


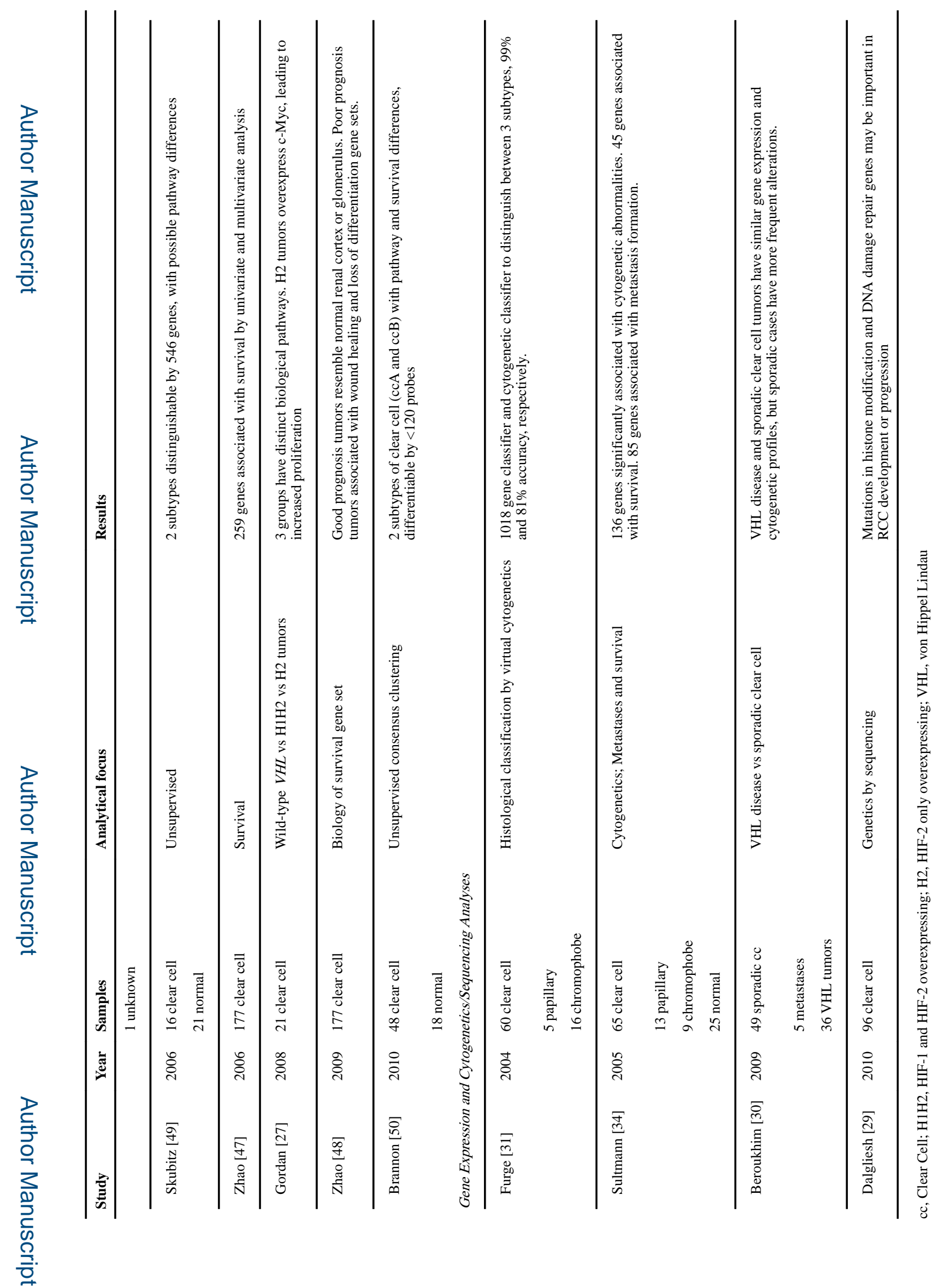

Eur Urol. Author manuscript; available in PMC 2016 May 23. 